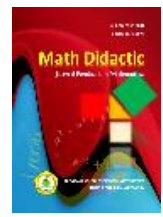

MATH DIDACTIC: JURNAL PENDIDIKAN MATEMATIKA

Volume 4 Nomor 2, Mei - Agustus 2018, halaman 128 - 135

Tersedia Daring pada http://jurnal.stkipbjm.ac.id/index.php/math

\title{
PENGEMBANGAN MODUL BERBASIS RISET PADA MATA KULIAH KALKULUS UNTUK MENINGKATKAN KREATIVITAS MAHASISWA
}

\author{
DEVELOPMENT OF RESEARCH-BASED MODULES IN CALCULUS COURSES TO \\ IMPROVE STUDENT CREATIVITY \\ Alfiani Athma Putri Rosyadi \\ Universitas Muhammadiyah Malang \\ athmaputri@gmail.com
}

\begin{abstract}
Abstrak: Penelitian ini bertujuan untuk 1) Mengembangkan modul berbasis riset pada mata kuliah kalkulus, 2) Mengetahui efektivitas modul berbasis riset pada mata kuliah kalkulus, dan 3) Mengetahui peningkatan kreativitas mahasiswa setelah menggunakan modul berbasis riset pada mata kuliah kalkulus. Jenis penelitian ini adalah penelitian dan pengembangan (research and development). Subyek dalam penelitian ini adalah mahasiswa prodi pendidikan matematika yang memprogram mata kuliah Kalkulus Diferensial pada tahun 2018. Metode pengumpulan data yang digunakan adalah angket, wawancara, tes dan lembar observasi. Analisis data yang digunakan adalah pengumpulan data, penyajian data dan reduksi data. Penelitian pengembangan modul berbasis riset pada mata kuliah kalkulus ini dikembangkan melalui tahap: a) Analisis Pendahuluan, b) menyusun modul berbasis riset, c) Validasi pada ahli media dan materi, d) Revisi modul berbasis riset, e) Penerapan modul berbasis riset, f) Pengumpulan data dan g) Analisis Data. Modul ini termasuk dalam kategori efektif berdasarkan penilaian dari validator dan angket mahasiswa. Setelah menggunakan modul ini terdapat peningkatan kreativitas mahasiswa terutama pada tahap originality. Pengembangan modul ini dikatakan efektif karena hasil skor validasi ahli dan penyebaran angket mahasiswa diperoleh skor 3,67 dalam kategori baik. Untuk peningkatan kreativitas mahasiswa setelah menggunakan modul berbasis riset dapat dilihat dari Hasil skor mahasiswa. Skor sebelum menggunakan modul adalah 73,47 dan skor sesudah menggunakan modul adalah 82,36
\end{abstract}

Kata Kunci : Modul Berbasis Riset, Kalkulus, Kreativitas

Abstract: This study aims 1) Develop research-based modules on calculus courses, 2) Know the effectiveness of research-based modules in the calculus course, and 3) Know the improvement of student creativity after using research-based modules on the calculus course. This type of research is research and development (research and development). Subjects in this study are students of mathematics education program of Calculus Differential course 2018. Data collection methods used questionnaires, interviews, tests and observation sheets. Data analysis used data collection, data presentation and data reduction. The research of this research-based module on the calculus course was developed through the following stages: a) Preliminary Analysis, b) developing researchbased modules, c) Validation of media and material experts, d) Revision of research-based modules, e) Implementation of research-based modules, Data collection and g) Data Analysis. This module was included in the effective category based on the assessment of the validator and student questionnaire. After used this module there is an increased in student creativity especially at the stage of originality. The development of this module was said to be effective because the results of expert validation scores and student questionnaire dissemination obtained a score of 3.67 in either category. To increase the creativity of students after using the research-based module can be seen from the results of student scores. The score before used the module was 73.47 and the score after used the module was 82.36

Keywords : research-based modules, calculus, creativity

Cara sitasi: Rosyadi, A.A.P. (2018). Pengembangan modul berbasis riset pada mata kuliah kalkulus untuk meningkatkan kreativitas mahasiswa. Math Didactic: Jurnal Pendidikan Matematika, 4(2), 128-135. 
Pembelajaran Berbasis Riset yang dikenal dengan PBR merupakan salah satu dari metode yang mengintegrasikan riset di dalam suatu proses pembelajaran. Selama ini proses pembelajaran yang berlangsung hanya berdasarkan pada silabus yang disusun oleh dosen pengampu. Riset di sini diartikan sebagai langkah - langkah terstruktur, sistematis, ilmiah, dan multi faset dalam mencari sebuah jawaban atas pertanyaan tertentu. Menurut Harsono (2005, hal. 13) Pembelajaran berbasis riset didasari filosofi konstruktivisme yang mempunyai empat tujuan yaitu: 1) pembelajaran membangun pemahaman mahasiswa, 2) pembelajaran dengan mengembangkan prior knowledge, 3) pembelajaran yang merupakan proses interaksi sosial antara mahasiswa dengan mahasiswa, dosen dengan dosen dan mahasiswa dengan dosen serta 4) pembelajaran bermakna yang dicapai melalui pengalaman nyata pada mahasiswa.

Langkah-langkah pembelajaran berbasis riset yang dapat diterapkan meliputi tiga tahapan antara lain: 1) tahap persiapan yang di dalamnya terdapat persiapan kondisi awal kelas sebelum diberikan pembelajaran, 2) tahap penerapan metode yang sudah disusun pada tahap sebelumnya, dan 3) tahap akhir dimana mahasiswa mempresentasikan hasil risetnya dalam bentuk poster atau artikel.

Berdasarkan hasil observasi peneliti selama mengampu mata kuliah kalkulus pada prodi pendidikan matematika sejak tahun 2011 sampai tahun 2017 diperoleh fakta yaitu: 1) mahasiswa cenderung menguasai teori tanpa mengetahui aplikasi pada dunia nyata, 2) mahasiswa mendapatkan referensi dari buku ajar saja, dan 3) mahasiswa hanya mengerjakan latihan soal yang ada di buku tanpa tahu bagaimana jika dihadapkan pada dunia nyata. Hal ini menjadi landasan peneliti untuk mengaplikasikan pembelajaran berbasis riset pada mata kuliah kalkulus. Selain itu, mata kuliah kalkulus merupakan salah satu fondasi penting untuk mengaplikasikan mata kuliah lain yang ada pada bidang kajian aljabar dan trigonometri.

Mata kuliah kalkulus pada prodi pendidikan matematika terdiri dari kalkulus diferensial dan kalkulus integral yang di dalamnya terdapat sebelas materi inti. Ke sebelas materi inti tersebut menjadi materi prasyarat pada mata kuliah yang lain. Sebagai contoh, materi fungsi yang ada pada kalkulus dibahas pada mata kuliah: analisis real, geometri analitik ruang, geometri transformasi dan mata kuliah lainnya. Itulah alasan peneliti memilih mata kuliah kalkulus sebagai kajian dalam penelitian ini.

Berdasarkan hasil penelitian (Rosyadi, 2017, hal. 12) diperoleh data bahwa mahasiswa masih mengalami kelemahan dalam aspek kreativitas untuk flexibility dan originality. Hal ini menunjukkan bahwa diperlukan bahan ajar yang dapat mendukung proses belajar dan mengajar untuk meningkatkan kreativitas mahasiswa. Modul merupakan salah satu alternatif yang dapat ditawarkan untuk meningkatkan kreativitas mahasiswa. Hal ini dapat dilihat dari tujuan utama penulisan modul yaitu untuk memfasilitasi mahasiswa dalam menuangkan idenya. Selain itu modul berbasis riset juga dapat menjadikan mahasiswa dapat mengaitkan teori dengan praktek yang ada pada kehidupan sehari-hari sehingga terjadi pembelajaran bermakna.

Berdasarkan latar belakang di atas maka peneliti mengangkat judul penelitian "Pengembangan Modul Berbasis Riset Pada Mata kuliah Kalkulus untuk Meningkatkan Kreativitas Mahasiswa”. Berdasarkan latar belakang di atas, dirumuskan permasalahan 
yang dapat dikaji pada penelitian ini sebagai berikut: 1) Bagaimana prosedur pengembangan modul berbasis riset pada mata kuliah kalkulus? 2) Bagaimana efektivitas modul berbasis riset pada mata kuliah kalkulus?, 3) Bagaimana peningkatan kreativitas mahasiswa setelah menggunakan modul berbasis riset pada mata kuliah kalkulus?

$\begin{array}{ccc}\text { Pembelajaran } & \text { Berbasis } & \text { Riset } \\ \text { merupakan metode } & \text { pembelajaran } & \text { yang }\end{array}$
menggunakan authentic learning, problemsolving, cooperative learning, contextual (hands on \& minds on, dan inquiry discovery approach yang dipandu oleh filosofi konstruktivisme (Widayati dkk, 2010, hal. 4). Filosofi konstruktivisme mencakup 4 (empat) aspek, yaitu: pembelajaran yang membangun pemahaman mahasiswa, pembelajaran dengan mengembangkan prior knowledge, pembelajaran yang merupakan proses interaksi sosial, serta pembelajaran bermakna yang dicapai melalui pengalaman nyata. Terdapat beberapa strategi dalam memadukan pembelajaran dan riset, yaitu; (1) memperkaya bahan ajar dengan hasil penelitian dosen, (2) menggunakan temuan-temuan penelitian mutakhir dan melacak sejarah, memperkaya kegiatan pembelajaran dengan isu-isu penelitian kontemporer, mengajarkan materi metodologi penelitian di dalam proses pembelajaran, (5) memperkaya proses pembelajaran dengan kegiatan penelitian dalam skala kecil, (6) memperkaya proses pembelajaran dengan melibatkan peserta didik dalam kegiatan, (7) memperkaya proses pembelajaran dengan mendorong peserta didik, dan (8) memperkaya proses pembelajaran dengan nilai-nilai yang harus dimiliki oleh peneliti (Umar dkk., 2011, hal. 22).

\section{Langkah-langkah Pembelajaran} Berbasis Riset antara lain:

1. Tahap Persiapan

Tahap persiapan ini adalah tahap mengondisikan kelas. Dosen dapat memberikan penjelasan kepada mahasiswa terkait dengan riset yang akan disusun. Selain ini dosen dapat memberikan beberapa contoh dan referensi dari riset yang sudah ada dan berkaitan dengan riset yang akan disusun. Pada tahap persiapan ini, mahasiswa diharapkan dapat aktif dan bisa menjelaskan apa yang sudah mereka baca dan pelajari tentang konsep yang sudah diberikan sebelumnya.

2. Tahap Penerapan Metode

Mahasiswa dapat menggunakan teori yang sudah pernah diperoleh pada mata kuliah metode penelitian lalu menggunakannya untuk menyelesaikan permasalahan yang sudah disusun pada tahap persiapan.

\section{Tahap Riset dan Publikasi}

Pada tahap terakhir, setelah mahasiswa memahami metodologi yang ada dan bisa menerapkannya untuk contoh riset skala kecil lalu mahasiswa diharapkan dapat menyelesaikan tugas besar. Tugas besar dalam hal ini adalah mereka diminta untuk menyelesaikan masalah di dunia nyata yang sudah disusun pada tahap persiapan, lalu menentukan metode yang sesuai lalu mempresentasikan hasil penelitian mereka. Publikasi hasil penelitian dapat dibuat dalam bentuk poster, jurnal dan artikel yang dapat didaftarkan pada jurnal, seminar nasional dan seminar internasional.

Modul adalah salah satu bagian dari bahan ajar yang menuntut kemandirian belajar mahasiswa. Dengan menggunakan modul mahasiswa yang mempunyai kemampuan tinggi akan dapat mengembangkan kemampuannya dengan mengerjakan kegiatan belajar yang lebih dulu. Mahasiswa dengan 
kemampuan yang sedang dan rendah juga bisa menyesuaikan dengan mendapatkan arahan dari dosen dalam menyelesaikan permasalahan yang ada pada modul. Di dalam modul pembelajaran berbasis riset terdapat tiga komponen utama yaitu:

1. Tahap Persiapan (PersiapanKu). Pada modul yang dikembangkan di dalamnya terdapat penjelasan singkat tentang riset yang akan disusun pada materi yang akan di bahas. Di dalam bagian ini juga terdapat apa saja yang diperlukan dan disiapkan dalam riset tersebut.

2. Tahap Penerapan (KerjaKu).

Tahap penerapan di dalamnya terdapat metode yang dipilih dalam menyelesaikan riset yang sudah ditentukan pada tahap sebelumnya. Hal ini dimaksudkan untuk memudahkan dalam menyelesaikan permasalahan yang sudah disusun pada tahap persiapan.

\section{Tahap Akhir (HasilKu)}

Pada tahap akhir, mahasiswa diberi kesempatan untuk menjelaskan riset yang sudah disusun dan diselesaikan dalam bentuk poster atau artikel. Artikel dan poster yang sudah disusun dapat direkomendasikan untuk dipresentasikan pada seminar nasional maupun kegiatan lainnya.

Pada setiap tahap yang ada dilengkapi dengan beberapa bagian yaitu:
1. Pendahuluan
2. Tujuan Pembelajaran
3. Latihan Soal
4. Kunci Jawaban
5. Penugasan

Kalkulus merupakan salah satu perkuliahan wajib yang ada pada prodi matematika. Di prodi dan jurusan lain juga terdapat mata kuliah ini, yang membedakan hanya pada tujuan akhir yang dicapai. Pada prodi pendidikan matematika untuk angkatan
2014, 2013, 2012, dan seterusnya mata kuliah kalkulus dibagi menjadi empat mata kuliah:
a. Kalkulus Diferensial (3 sks)
b. Kalkulus Integral (3 sks)
c. Kalkulus Peubah Banyak (3 sks)
d. Fungsi Khusus (3 sks)

Untuk angkatan 2017 berdasarkan KPT maka hanya dibagi dua mata kuliah yaitu:
a. Kalkulus Diferensial (4 sks)
b. Kalkulus Integral (4 sks)

Materi kalkulus yang akan disajikan pada modul ini antara lain sebagai berikut.

1. Fungsi

2. Limit

3. Kekontinuan

4. Turunan

5. Integral

6. Fungsi Peubah Banyak

7. Turunan Parsial

8. Integral Lipat

9. Fungsi Gamma

10. Fungsi Beta

11. Fungsi Legendre

Ke sebelas materi tadi terdapat pada sajian mata kuliah kalkulus diferensial, kalkulus integral, kalkulus peubah banyak dan fungsi khusus.

Kreativitas sering kali diartikan sebagai cara berpikir divergen, yang berbeda dengan cara pikir kebanyakan orang. Menurut Torrance dalam Bart dkk (2015, hal. 33) kreativitas adalah kemampuan untuk merasakan masalah, membuat tebakan, menghasilkan ide baru dan mengomunikasikan hasilnya. Seorang mahasiswa dikatakan kreatif jika dapat menganalisis masalahnya, menyusun strategi yang sesuai, lalu dapat 
mengomunikasikan apa yang sudah ditafsirkan tersebut dalam bahasa dan gayanya sendiri.

Indikator seorang mahasiswa dikatakan kreatif dapat dilihat dari empat aspek yaitu: 1) Fluency, yaitu kemampuan untuk cepat dan mudah menghasilkan ide

2) Flexibility, adalah kemampuan untuk mengubah dan merestruktur kemampuan pemecahan masalah secara efektif dan memindahkannya dalam konteks yang berbeda

3) Originality, kemampuan untuk menghasilkan ide baru dan solusi yang tidak biasa

4) Development, kemampuan untuk merencanakan aktivitas sedetail-detailnya dan kemampuan untuk memprediksi hasil final untuk mengembangkan ide

5) Attention the problem, kemampuan untuk secara mudah mengamati fenomena tidak biasa.

6) Reorganization, kemampuan untuk menggunakan obyek atau bagian dari obyek dalam cara yang baru dan tidak biasa.

Pada penelitian ini indikator kreatif meliputi tiga aspek yaitu: 1) Fluency, 2) Flexibility, dan 3) Originality

\section{Metodologi Penelitian}

Jenis penelitian ini adalah penelitian dan pengembangan (research and development). Menurut Rosyadi, dkk (2016, hal. 11) Penelitian dan pengembangan adalah metode penelitian yang digunakan untuk menghasilkan produk tertentu dan menguji keefektifan produk tersebut. Penelitian ini adalah mengembangkan modul yang berbasis riset. Pendekatan yang digunakan adalah deskriptif kualitatif

Subyek dalam penelitian ini adalah mahasiswa prodi pendidikan matematika yang memprogram mata kuliah Kalkulus
Diferensial dan Kalkulus Integral pada tahun 2018. Jumlah mahasiswa pada uji coba produk penelitian ini adalah 10 orang mahasiswa yang sudah menempuh mata kuliah kalkulus diferensial, Kalkulus Integral dan kalkulus Peubah Banyak pada tahun 2018.

Pada penelitian ini prosedurnya sesuai dengan langkah-langkah berikut.

1. Analisis Pendahuluan. Pada tahap ini peneliti melakukan kajian terhadap referensi dan kurikulum untuk penyusunan modul berbasis riset.

2. Menyusun modul berbasis riset

3. Validasi pada ahli media dan materi

4. Revisi modul berbasis riset

5. Penerapan modul berbasis riset

6. Pengumpulan data

7. Analisis Data

Data dikumpulkan melalui angket, wawancara dan lembar observasi.

1. Angket

Angket disusun untuk mengetahui keefektifan dari modul yang sudah dikembangkan. Apakah mahasiswa dapat memahami konsep yang disajikan pada kegiatan modul berbasis riset. Selain mahasiswa, juga terdapat angket validasi untuk mengetahui keefektifan modul.

2. Wawancara

Wawancara digunakan untuk menjelaskan data yang diperoleh melalui angket dan observasi yang ada di kelas. Pengumpulan data menggunakan wawancara diharapkan lebih mendalam informasi yang didapat dari mahasiswa.

3. Lembar Observasi

Lembar observasi digunakan untuk mengetahui kreativitas mahasiswa selama menggunakan modul berbasis riset. Selain itu, lembar observasi juga digunakan untuk mengetahui keterlaksanaan modul berbasis riset pada mahasiswa. 


\section{Tes}

Tes digunakan untuk mengukur tingkat kreativitas mahasiswa selama menggunakan modul berbasis riset. Tes yang disusun mencakup indikator-indikator kreatif yang sudah ditentukan peneliti.

Analisis data pada penelitian ini antara lain sebagai berikut.

a. Reduksi data. Data yang sudah dikumpulkan kemudian direduksi sehingga diperoleh data yang sesuai untuk diteliti. Data diperoleh dari hasil angket, lembar observasi, tes dan wawancara.

b. Penyajian data. Data yang sudah direduksi dapat disajikan dalam bentuk tabel ataupun grafik, hal ini dilakukan untuk memudahkan membaca dari data yang diperoleh.

c. Uji Efektivitas Data. Pada tahap ini adalah menganalisis hasil dari pengumpulan data, yaitu hasil tes, wawancara, observasi dan angket. Modul berbasis riset dikatakan kreatif apabila: memenuhi kategori baik dalam validasi modul oleh validator dan angket modul untuk mahasiswa.

\section{Hasil Penelitian dan Pembahasan}

Penelitian ini dilaksanakan selama satu semester dimana subjek penelitian adalah mahasiswa kelas IIA dan IIB angkatan 2017. Mahasiswa diberikan modul pada mata kuliah kalkulus diferensial. Modul yang diberikan diposting dalam edmodo yang rutin dibagikan dosen setiap minggu. Hal ini dilakukan agar mahasiswa dapat membaca materi sebelum perkuliahan dimulai.

Proses pembelajaran yang dilakukan diawali dengan presensi, menyampaikan tujuan pembelajaran pada hari ini dan memberikan informasi awal tentang materi yang akan dibahas dan meminta mahasiswa mengerjakan modul pembelajaran pada setiap kelompok. Kelompok sudah dibagi dari pertemuan sebelumnya, hal ini dilakukan untuk mengefektifkan waktu. Juga sudah dicetak mahasiswa melalui edmodo beberapa hari sebelum perkuliahan.

Selama proses mengerjakan modul, mahasiswa diberi kesempatan untuk menanyakan apabila mengalami kesulitan. Selama proses diskusi, ada beberapa mahasiswa yang maju ke depan untuk menanyakan materi yang tidak dipahami selama melakukan diskusi. Setelah proses pembelajaran, mahasiswa diminta untuk mengerjakan

Berikut adalah hasil skor mahasiswa setelah menggunakan modul dalam mengerjakan soal tes.

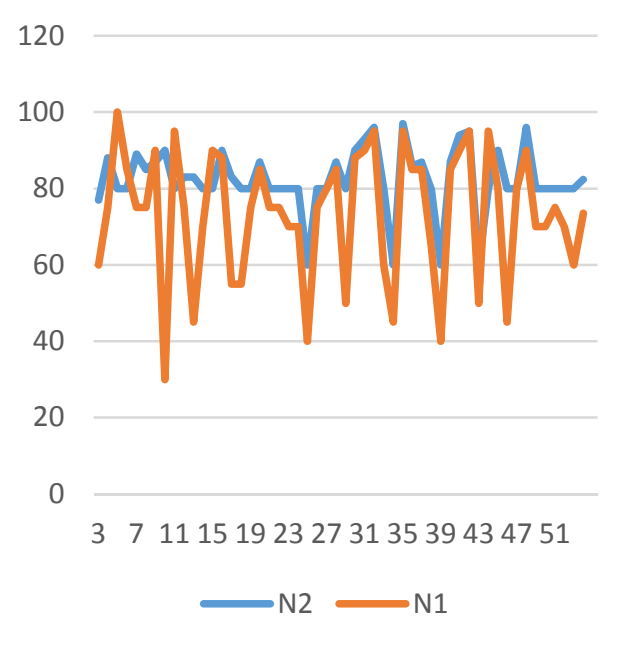

Gambar 1. Skor mahasiswa sebelum dan sesudah menggunakan modul.

Keterangan :

$\mathrm{N} 1$ adalah nilai awal sebelum diberikan modul $\mathrm{N} 2$ adalah nilai nilai akhir sesudah diberikan modul 
Hasil skor mahasiswa menunjukkan bahwa adanya perubahan skor setelah diterapkan modul pembelajaran. Skor sebelum menggunakan modul adalah 73,47 dan skor sesudah menggunakan modul adalah 82,36.

Berdasarkan hasil angket oleh validator diperoleh skor 3,67 dalam kategori baik. Selain menggunakan tes, hasil dari validasi terhadap modulnya antara lain sebagai berikut

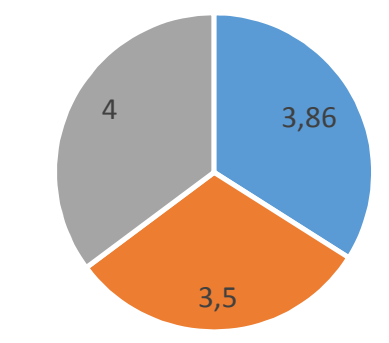

- Materi Penyajian - Bahasa

Gambar 2. Skor Hasil Validasi Ahli

Berdasarkan hasil penelitian dapat diperoleh bahwa pembelajaran dengan menggunakan modul pembelajaran berbasis riset dapat meningkatkan kreativitas mahasiswa. Hal ini dapat dilihat dari peningkatan skor mahasiswa. Hal ini sejalan dengan penelitian Roach (2000, hal. 32) yang mengatakan bahwa pembelajaran berbasis proyek bisa meningkatkan

\section{Simpulan dan Saran}

\section{Simpulan}

Penelitian ini mengembangkan modul berbasis riset pada mata kuliah kalkulus ini yang dilaksanakan melalui tahap: a) Analisis Pendahuluan, b) menyusun modul berbasis riset, c) Validasi pada ahli media dan materi, d) Revisi modul berbasis riset, e) Penerapan modul berbasis riset, f) Pengumpulan data dan g) Analisis Data. Modul ini termasuk dalam kategori efektif berdasarkan penilaian dari validator dan angket mahasiswa. Setelah menggunakan modul ini terdapat peningkatan kreativitas mahasiswa terutama pada tahap originality.

Pengembangan modul ini dikatakan efektif karena hasil skor validasi ahli dan penyebaran angket mahasiswa diperoleh skor 3,67 dalam kategori baik. Untuk peningkatan kreativitas mahasiswa setelah menggunakan modul berbasis riset dapat dilihat dari Hasil skor mahasiswa. Skor sebelum menggunakan modul adalah 73,47 dan skor sesudah menggunakan modul adalah 82,36

\section{Saran}

Saran yang dapat peneliti sampaikan untuk beberapa pihak antara lain:

a. Untuk Mahasiswa

Mahasiswa diharapkan dapat mencari referensi tambahan untuk lebih meningkatkan kreativitasnya.

b. Untuk Dosen

Menyusun perangkat pembelajaran dan bahan ajar yang sesuai dengan karakteristik mahasiswa.

c. Untuk peneliti lain

Mengolaborasikan modul dengan strategi dan pendekatan lain yang sesuai.

\section{Daftar Pustaka}

Bart, W. M., Hokanson, B., Sahin, I., \& Abdelhady, M. (2015). An investigation of the gender differences in creative thinking abilities among 8th and 11th grade students $\leftleftarrows$. Thinking Skills and Creativity, 17, 17-24

Griffith Institute for Higher Education, 2008, Research-based learning: strategies for 
successfully linking teaching and research. University of Griffith.

Harsono, 2005, Pengantar Problem-Based Learning. Medika, Yogyakarta, Indonesia.

Pusat Pengembangan Pendidikan, 2009, Naskah Akademik Student Teacher Aesthetic Role- sharing (STAR), Universitas Gadjah Mada, Yogyakarta, Indonesia

Roach M., Blackmore P., Dempster J., 2000, Supporting High-Level Learning Through Research-Based Methods: interim guideline for course design, TELRI Project-University of Wrwick.

Rosyadi, Alfiani A.P (2016). Kalkulus untuk Teknik. Malang: CV Ampuh Multi Rejeki.

Rosyadi, Alfiani A.P dkk(2016). Metodologi Penelitian, Malang : UMM Press.

Rosyadi, Alfiani A.P dkk (2017). Penerapan Model Guided Discovery Learning Dengan Mind Mapping Untuk Meningkatkan Kreativitas Mahasiswa. Jurnal Derivat.

Umar, Masri Kudrat dkk. (2011). Pengembangan Pembelajaran Berbasis Riset di Program Studi Pendidikan Fisika FMIPA Universitas Negeri Gorontalo.

Widayati Dkk. (2010). Pedoman Umum Pembelajaran Berbasis Riset (PUPBR). Universitas Gadjah Mada 